\title{
Municipal Thematical and Territorial Indicator Systems for Sustainable Socio-Ecological Coastal Governance
}

\author{
Janis Kaulins, Raimonds Ernsteins, Ivars Kudrenickis, \\ Anita Lontone, Ilga Zilniece \\ Environmental Science Department, University of Latvia, Riga, Latvia \\ E-mail: raimonds.ernsteins@lu.lv (corresponding author)
}

Received 08 March; accepted 24 March 2017

\begin{abstract}
There are recognized in Latvia the lack of locally based coastal socio-ecological research knowledge and its interpretation into municipal safety and development planning from one side as well as also only land-side oriented and separate sectorial development interests based coastal municipalities' governance/planning practice from other side. Coastal governance practice development problems solution at the local level are to be seen at both ends of governance cycle - coastal situation evaluation (e.g. science) and policy design and implementation. Overall objective is to create, apply/test and use applicable interface system for integrated coastal science transfer into integrated coastal management (ICM), and so altogether developing whole and flexible integrated coastal governance (ICG) cycle, esp. at the local municipal level, but also coping with vertical integration with other national and international governance levels, as well as horizontal integration with other municipal development sectors.

ICG complex interface system has been started to develop step-wise during realization of various research and development projects and particularly by designing and testing both complementary thematical and territorial approaches based municipal indicator systems (IS). Approaches were applied as different cross-sectorial municipal IS (coastal, climate change governance, coastal risk etc.) and, interrelatedly, eventual whole municipal development IS. There was designed and implemented Sustainable development governance IS proposal for Saulkrasti municipality, being used now for supervision of mandatory municipal long term planning document - Sustainable Development Strategy. Further proposals for coastal indicators observatory system for sealand border area administrative territories has to be developed, respecting all types of coastal components as for highly specific socio-ecological systems in the Baltic Sea region area.
\end{abstract}

Keywords: integrated coastal governance, socio-ecological coastal systems, coastal interface system, indicator systems, climate change governance, complementary instruments.

Jel Classification: Q01.

Conference topic: Sustainable Economics Development.

\section{Introduction}

Integrated coastal management (ICM) has been long standing recommended research/model practice and EU requirements approach and even principle for coastal areas development, but still being comparatively new tradition as barely used in the country and even region. Also the next stage of ICM development into integrated coastal governance (ICG) or comparatively similar concept of sustainable coastal governance (SCG) has still not been recognized as everyday practice. ICG studies in Latvia do recognize several quite known general problem fields missing work with/within whole governance process cycle and real stakeholder's partnership/ownership approaches, one sided (mainly land based) and sector based planning approach to coastal areas, and often not tackling coast as one governance territory (despite administrative division) and its development resource as not being perceived as complex socio-ecological systems. Subsequently, after our studies, there should be basically confirmed the need for coastal integrity understanding and collaboration both within and between stakeholder's groups, at all sectors, levels, sustainability dimensions complementary.

Basic solutions for mentioned problems do require for both, decision-makers/planners and society with general/specific groups, to have necessary coastal communication developments - information, education, participation and behavior - and starting first with quantitative and qualitative information assessment of governance particularly and for coastal sustainability in general. Coastal research, having especially socio-economic part as well, shall be transferred into ICG info-decisions. Such mostly missing information may be gained from systematic and

(C) 2017 J. Kaulins, R. Ernsteins, I. Kudrenickis, A. Lontone, I. Zilniece. Published by VGTU Press. This is an open-access article distributed under the terms of the Creative Commons Attribution (CC BY 4.0) License, which permits unrestricted use, distribution, and reproduction in any medium, provided the original author and source are credited. 
regularly met measurements of strictly defined parameters, which form the indicator system for ICG. The main results of research refer on construction of indicators itself and on building of indicator systems as a management and communication tool for coastal integrated planning and management. Principal integration approach is necessary at any step of the process to be realized - from coastal science to municipal monitoring and sustainability indicators into ICG.

This has been started to test step-wise during realization of various research and development projects: to translate and integrate academic coastal science based results into to be designed an applied municipal land-water boundary monitoring and indicator system; to integrate this auditing knowledge into the whole municipal coastal governance cycle process/products with innovating and facilitating ICG decision-making and policy renewal, complementary instruments based planning and implementation; to design an integrated coastal science and governance communication content/products and to prepare stakeholders participated communication process with integrated instruments development. Most advanced coastal governance process and content assessment status in Latvia has been reached at Saulkrasti coastal municipality (Table 4), where general territorial indicator system proposal was elaborated after interdisciplinary studies and stakeholder discussions, finally formally approved/implemented by municipality to be used both for information acquisition and structuring in the planning process and as a part of supervision of municipal Sustainable Development Strategy, as now formally/legally required planning document in Latvia at all governance levels.

\section{Framework, general approaches and methods}

The indicator systems (IS) for sustainable development governance (SDG) had been developing initially on the basis of environmental indicators, later environmental, social and economic dimensions gradually became more evenly balanced and were more often supplemented by the fourth dimension - the governance dimension (Alberta et al. 2016; Ernšteins et al. 2009, 2011; Hezri, Dovers 2006; Mascarenhas et al. 2010, 2014; Moreno, Fidelis 2015; Rinne et al. 2013; Valtenbergs et al. 2013). Important contribution for practically applicable IS has been given by FAO producing theoretical outlines and practice conclusions. The IS formation models were based upon functional analysis of system to be researched (Bossel 2001) or the problem analysis of the territory (Rydin et al. 2003; Comino, Ferretti 2016), but were randomly linked with the governance of the territory and consequently with the content of official development planning documents, e.g. process of making governance decisions, however now step-wise being more and more under detailed investigation and practice application (Bowen, Riley 2003; Becker 2005; Moldan et al. 2012). From the communication point of view the IS shall be understand as the central part of wider science-policy-practice interface (Kudrenickis et al. 2016).

The IS for the measurement of coastal sustainability differs from the general system with its hard spatial character: coast is formed by coastline with related set of other geo-spatial elements. These elements could not be defined equivocally; they have different spatial distribution characteristics, depending from their geo-spatial properties (Pužulis 2010). Therefore, the indicator system, by the help of which, the coastal sustainability is assessed, must at least be capable of distinguishing the coast from the hinterland and compare them among themselves, clarifying the origin of impacts that determine the condition of coast and development tendencies and provide insight about how coastal impacts are distributed along the governance territory.

Following the character of spatial distribution of data, four main types of defining coastal areas can be distinguished (Marti et al. 2007): administrative-territorial, coordination character, geometric buffer and combined one that contains features of locus and administrative territorial ones. It is worthwhile to distinguish the fifth type as well - according to planning elements in Latvian circumstances (coastal protection borders). The character of data determines not only types of coastal definition, but also the spatial relationships of indicators with the coast: special coastal indicators, decisive coastal indicators, characterizing elements not specific to the coast, but where it is possible, spatially correctly evaluate coastal related impacts and relatively decisive coastal indicators, where the spatial distribution of data is "unclear", not allowing to estimate these impacts correctly, but our common knowledge about territory allow evaluate them in qualitative way.

According to the general purpose, there were selected related set of complementary research methods representing both academic and applied studies, and, elaborated traditional step-wise research and development (R\&D) process approach in order to construct and test separate SDG indicator systems (IS) application in the governance process. Working with design and construction of it should be recognized and taken as overall approach for R\&D work, that municipal IS building requires integration of the IS into development planning/management process and development planning documentation finally, for eventual approval by municipal Council.

The following main groups of research methods were complementary used: (1) case study research (CSR), which implies acquisition of thematically coordinated information during the field studies [26] using the analysis of socio-economic and natural environment data, document studies, field observations, interviews with target group representatives and focus groups, inquiries (not all methods must be included for particular specific study); (2) approbation research, using various possibilities of testing R\&D results; (3) expert interviews beyond the CSR frame. Coastal studies of corresponding indicator systems (coastal, climate change governance, coastal risk etc.) has 
been realized at several municipalities using CSR method (including interviews, questionnaires, document analysis etc.) for revealing the link between the planning documents (mandatory for all stages of governance) and the evaluation of the possibilities for using the indicator system method, and for research of communicative function of indicators. Each CSR case included 30-50 interviews and at least 1-2 focus groups. The expert interviews (altogether 15) were complementary with CSR and the interviews included also information about the aspects of integrated planning and indicator usage in elaboration of municipal development planning documents. Also three types of approbations have been employed: in workshops of practical research, in the planning process and the full scale approbation at the Saulkrasti municipality - IS for coastal municipal sustainable development governance.

SDG indicators developed for coastal social-ecological systems must be viewed as the product of multidisciplinary coastal research as to be seen in our general framework proposal (Fig. 1). Based upon usage of indicator system, the approach of assessment and reflection of specialized sustainability aspects was approbated during our R\&D projects from thematical and territorial viewpoint as to be seen in the next chapters. From thematic viewpoint, it has resulted in elaboration of indicator systems for evaluation of: sustainability of Latvian coast, by adapting EU DEDUCE coastal indicator system to the national level circumstances of Latvia; Climate change adaptation strategy implementation in the Salacgrīva municipality; description of specific cross-sector of economics - the governance of health and environmental-friendly life cycle of food (food systems governance) also in Salacgrīva. From territorial viewpoint, the proposals have been elaborated for SDG indicator systems, implemented and tested in Saulkrasti municipality, and, proposed also for Salacgriva municipality.

\section{Results and discussion: indicator systems for thematical and territorial governance}

Thematical and territorial governance IS development studies have been planned as step-wise realized R\&D program - having academic and applied research components and afterwards preparing policy initiatives and testing them into municipal practice in joint collaboration with municipal governance and as possible also with necessary participation of all main stakeholder's groups. Several thematical IS have been elaborated, but not fully implemented by municipalities due to various reasons, particularly due to voluntary character of thematical planning in the municipalities linked with financial constraints and limited administrative/planning resources. However, for territorial governance approach, obviously being mandatory, full scale testing and legal application of sustainable development governance IS for Saulkrasti municipality has been successfully done. All examples will follow now.

\section{Coastal indicator system developments in general}

Initially, already in 2007 the complex overview was produced about condition of coastal sustainability of the country, using readings from indicator system. The summary of the assessment of coastal sustainability of Latvia in accordance with the data obtained from EU DEDUCE project ((Marti et al. 2007; Ernšteins et al. 2009) is following:

- The difference between Latvian coast and hinterland, on the whole, are insignificant, only certain indicators show significant peculiarities;

- Development activities are concentrated in restricted areas, mainly associated with the influence areas of large cities. The rest of the territory is scarcely inhabited, with poor infrastructure and development of economic activities;

- Conservation currently prevails upon the development therefore it cannot be asserted that Latvian coast is characterized by sustainable development. Here the essential difference from the initial assumption of the project is seen and the actual situation in majority of project partner states with respect to the coast as the place of problem concentration, which is associated intensive use of coastal areas with excess of anthropogenic pressures and demands immediate and complex coastal protection;

- Coastal areas have considerable potential for development of economic activities and welfare, even considering the necessary requirements of sustainability principle and the related restrictions of usage of ecosystem services.

- The peculiarity of the Latvian coast is the existence of two types of extremely different coastal zones: urban and rural/ small town type territories.

- Problematic is the situation in capital city Riga: agglomeration bordering with the sea, but the main activities are slightly removed inland; the impacts on the sea take place through the River Daugava and the port, as well as in the summer season through the migration of residents in search of coastal services in the direction of Jūrmala.

Good adaptive SCG shall have to possess both, not only top-down, but also bottom-up, from local municipal level and public monitoring build, indicator systems, being characterized by horizontal integration and vertical integration across governance levels and respecting specific characteristics of coastal area via some developed typology, using physical and socio-economical characteristics, as for specific socio-ecological system, requiring also comparison with wider reference territories for obtaining real impacts of/to sea-land border area. 


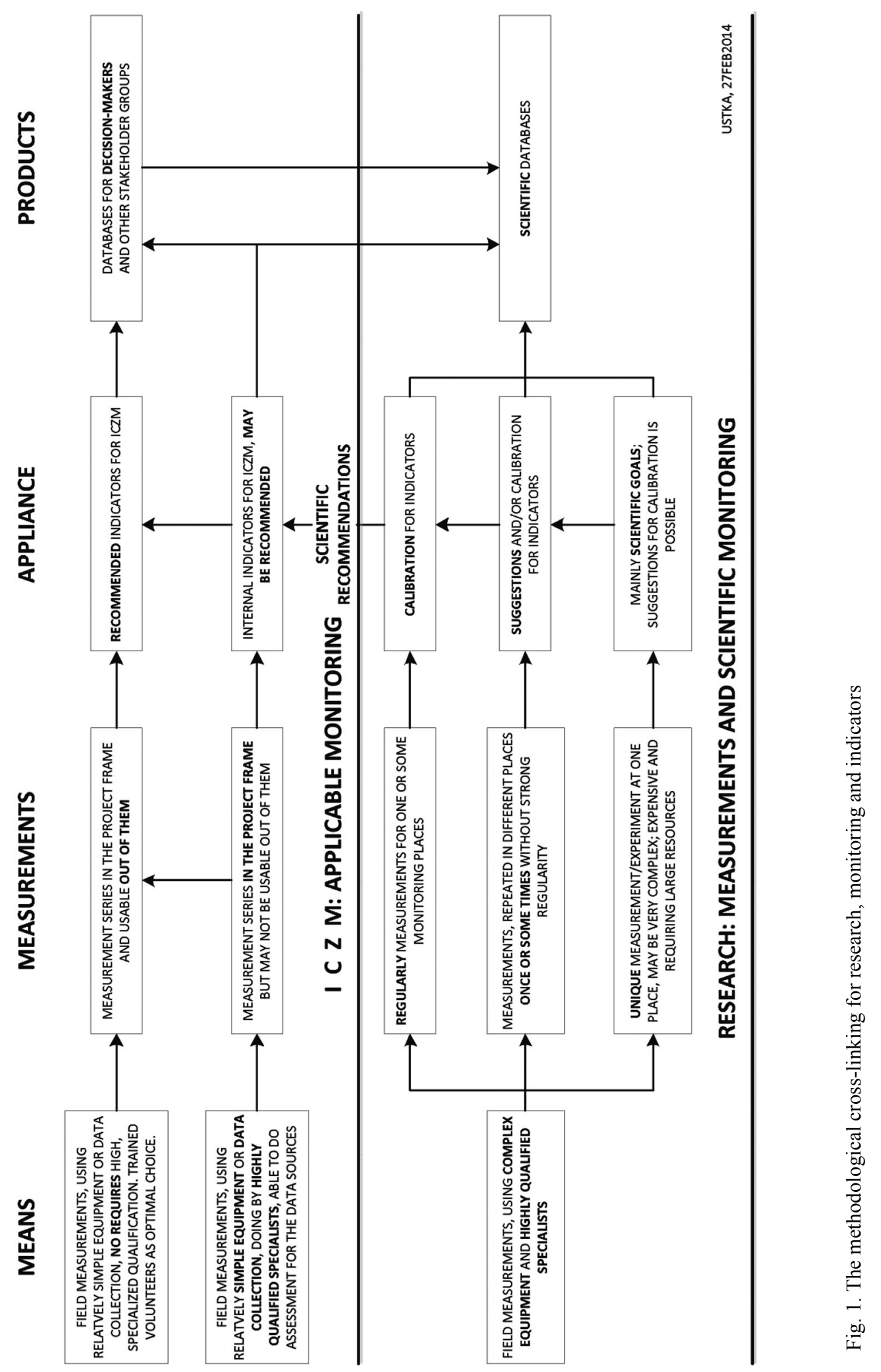



sustainable socio-ecological coastal governance

Reviewing problem situations in relation towards sustainability dimensions, it can be seen, that there are three different types of problem fields and correspondingly, indicators can be divided into 3 groups according to these types: sub-sectoral indicators - describe certain course of action, related to certain sector within one sustainability dimension; sectoral (or one-dimension) indicators - describe course of action or its group, related to the whole sustainability dimension; integrative indicators - describe courses of action related to integrative problem areas, i.e., are referred to at least two sustainability dimensions. Examining all the system on the whole, the fourth group can also be identified - integral also strategic indicators - describe the main and the general indicators of the governed system that characterizes the given governance system on the whole and/or in comparison with similar systems. The interconnectedness of indicators is determined by indicator integrativity, which characterizes the relationships of certain indicators with sustainability dimensions and their interaction areas that allow formation of balanced indicator systems for sustainable development planning, supervision and assessment.

There can be developed generic indicators system model (Fig. 1) which might be adapted for particular coastal area classification (CAC). Application of the CAC, depending on the physical characteristics (and eventually also some socio ones as well) of littoral zone, provides the possibility to supplement obtained indicators in the pilot territories with local level indicators obtained by applying the comparatively simple methodology of their determination. The CAC concept is therefore innovative concept in relation to ICG practice, providing possibility to determine mutually comparable and relatively homogeneous coastal territories/areas, where research is limited.

Coastal indicators observatory system could be developed for sea-land border area administrative territory and even for several countries (or later the whole region), being "bottom-up" build (starting from local level) as set of indicator systems, characterized by vertical integration. Obviously as said before, for ICG must be respected the specific characteristics of coastal area through creating of some typology/classification, using physical and socioeconomical characteristics, since coastal areas are specific socio-ecological systems, requiring comparison with wider reference area for obtaining of real impacts from presence of sea-land border. At the beginning, this system may include morphologically relatively homogenous coastal areas. Coastal observatory could be built on basis of multidisciplinary indicator system DEDUCE. System must be deeper adapted depending on the specific characteristics of coastal area and information storage and production peculiarities at different countries. System shall be a reliable source of information and interdisciplinary decision making on Baltic region coastal problems/development for all stakeholders, incl. NGO's and wider society, too.

\section{National thematical coastal indicator system proposal for Latvia}

After finishing the DEDUCE project (Marti et al. 2007) mentioned above, there was elaborated sustainable coastal development (SCD) indicator system proposal for measuring coastal sustainability in Latvia (Ernšteins et al. 2009), being based on the one developed in the DEDUCE study (Table 1). There are recognized main geographical and socio-economic conditions, spatial scale differences in sustainability evaluation measurements and also data availability in Latvia. The structure of indicator system is provided in the table below. System proposal distinguishes eight SCD sector goals (one more as for DEDUCE) and the development of each sector is to be measured by chosen set of 24 indicators (in total by 34 measurements): appropriate control of further development of the undeveloped coast; protect, enhance and celebrate natural and cultural diversity; promote and support a dynamic and sustainable coastal economy; ensure that beaches are clean and that coastal waters are unpolluted; reduce social exclusion and promote social cohesion in coastal communities; use natural resources wisely; recognise the threat to coastal zones posed by climate change and ensure appropriate and ecologically responsible coastal protection; develop human resources and integrated management capacity. For the $8^{\text {th }}$ goal there is developed grouping of several integrative indicators, which shall provide information on coastal governance particularly on the efficiency of coastal communication process, what needs further testing and elaboration upon to reflect the following: coastal awareness among the population; state of environment and evaluation of development tendencies; state of local economy and evaluation of development tendencies; evaluation of work of municipalities; evaluation of planning. In most of cases it can be acquired only directly from interviews and questioners, but which shall be done not so often, obviously.

Sampling frequency is relative and individual, taking into account the character of the appropriate coastal process as well as general dynamics of socio-economic processes in Latvia. In many cases acquired data are of satisfying quality in both spatial and temporal terms, but access to them should be improved. Information, acquired and processed by state statistics institution, is limited in terms of spatial resolution, which does not allow a comprehensive evaluation of coastal sustainable development yet. Unfortunately, also all realted administrative risks, affecting introduction of such or similarly developed indicator system should be not forgotten.

\section{Municipal level and collaboration governance instruments introduction - coastal climate change adaptation}

Obviously, ICG is directly linked with the planning and actions for climate change adaptation. The climate changes significantly affect the provision of services for the coastal territories and there is a need to improve governance practice (Ernšteins et al. 2014), particularly first of all with top-down basic approaches by municipalities - to find principles and appropriate structural frameworks for integration of climate change adaptation issues within both 
Kaulins, J.; Ernsteins, R.; Kudrenickis, I.; Lontone, A.; Zilniece, I. Municipal thematical and territorial indicator systems for sustainable socio-ecological coastal governance

Table 1. Sustainable coastal development governance indicator system proposal for national level in Latvia (Source: Ernsteins et al. 2009)

\begin{tabular}{|c|c|c|c|c|}
\hline Goal & Indicator & Measurement & $\begin{array}{l}\text { Proposed responsible institution for } \\
\text { measurement }\end{array}$ & $\begin{array}{l}\text { Sampling } \\
\text { (years) }\end{array}$ \\
\hline \multirow{6}{*}{ I } & 1 & $\begin{array}{l}\text { Size and proportion of the population living in the coastal } \\
\text { zone }\end{array}$ & $\begin{array}{l}\text { Central Statistical Bureau of Latvia } \\
\text { (CSB) }\end{array}$ & 5 \\
\hline & 2 & $\begin{array}{l}\text { Area (percent) of built-up land (by distance from the } \\
\text { coastline) }\end{array}$ & \multirow{2}{*}{$\begin{array}{l}\text { Latvian Environment, Geology and } \\
\text { Meteorology Centre (LEGMC) }\end{array}$} & 5 \\
\hline & \multirow{2}{*}{3} & Rate of development on previously undeveloped land & & 5 \\
\hline & & New development of previously developed land & Municipalities & 5 \\
\hline & 4 & Volume of traffic on main coastal motorways & SJSC "Latvian State Roads" & 5 \\
\hline & 5 & Proportion of agricultural land farmed intensively & \multirow{2}{*}{ LEGMC } & 5 \\
\hline \multirow[b]{2}{*}{ II } & 6 & Area of semi-natural habitats & & 5 \\
\hline & 7 & Area of protected biotopes in coastal zone & $\begin{array}{l}\text { Faculty of Biology of University of } \\
\text { Latvia }\end{array}$ & 5 \\
\hline \multirow{6}{*}{ III } & \multirow{2}{*}{8} & Full time, part time and seasonal employment per sector & \multirow{2}{*}{ CSB \& municipalities } & 1 \\
\hline & & Value added per sector & & 1 \\
\hline & 9 & Total volume of goods handled per port & CSB & 1 \\
\hline & \multirow{2}{*}{10} & Number of overnight stays in tourist accommodation & \multirow{3}{*}{ CSB } & 1 \\
\hline & & Occupancy rate of bed places & & 1 \\
\hline & 11 & Ratio of overnight stays par number of residents & & 1 \\
\hline \multirow{5}{*}{ IV } & 12 & $\begin{array}{l}\text { Percent of coastal bathing waters compliant with the guide } \\
\text { value of the European Bathing Water Directive }\end{array}$ & Health Inspection & 1 \\
\hline & 13 & Volume of litter collected per given length of shoreline & CSB \& citizen science application & 1 \\
\hline & 14 & $\begin{array}{l}\text { Average winter concentrations of nitrates and phosphates in } \\
\text { coastal waters }\end{array}$ & $\begin{array}{l}\text { LEGMC \& Institute of Aquatic } \\
\text { Ecology }\end{array}$ & 1 \\
\hline & \multirow[b]{2}{*}{15} & Volume of accidental oil spills & \multirow{2}{*}{$\begin{array}{l}\text { Marine and Inland Waters } \\
\text { Administration of the State } \\
\text { Environmental Service }\end{array}$} & 1 \\
\hline & & Number of observed oil slicks from aerial surveillance & & 1 \\
\hline \multirow{5}{*}{$\mathrm{V}$} & 16 & Indices of social exclusion in coastal zone & CSB & 1 \\
\hline & \multirow{3}{*}{17} & Average household income & CSB \& State Revenue Service & 1 \\
\hline & & Percent of population with a higher educational qualification & CSB & 5 \\
\hline & & Value of residential property & State Land Services & 5 \\
\hline & 18 & Ration of first to second homes & CSB \& State Revenue Service & 5 \\
\hline \multirow{3}{*}{ VI } & \multirow{3}{*}{19} & State of the main fish stocks by species and sea area & \multirow{3}{*}{ BIOR, national institute } & 5 \\
\hline & & Landings by species & & 1 \\
\hline & & Value of landings by port and species & & 1 \\
\hline \multirow{4}{*}{ VII } & \multirow[b]{2}{*}{20} & Length of protected and defended coastline & $\begin{array}{l}\text { Latvian Geospatial Information } \\
\text { Agency }\end{array}$ & 10 \\
\hline & & Length of dynamic coastline & $\begin{array}{l}\text { LEGMC \& University of Latvia, } \\
\text { Faculty of Geography and Earth } \\
\text { sciences }\end{array}$ & 10 \\
\hline & 21 & Number of people living within "at risk" zone & $\begin{array}{l}\text { Municipalities \& LEGMC \& UL } \\
\text { Faculty of Geography and Earth } \\
\text { sciences }\end{array}$ & 10 \\
\hline & & Value of economic assets within "at risk zone" & $\begin{array}{l}\text { State Land Services \& Latvian } \\
\text { Geospatial Information Agency }\end{array}$ & 10 \\
\hline \multirow{5}{*}{ VIII } & 22 & Coastal awareness of population living in coastal zone & \multirow{5}{*}{$\begin{array}{l}\text { Municipalities \& UL Faculty of } \\
\text { Geography and Earth sciences }\end{array}$} & $3-5$ \\
\hline & \multirow{4}{*}{24} & \multirow{4}{*}{ Assessment of state and tendencies } & & $5-10$ \\
\hline & & & & $5-10$ \\
\hline & & & & $5-10$ \\
\hline & & & & 5-10 \\
\hline
\end{tabular}



sustainable socio-ecological coastal governance

types of statutory municipal documents - municipal long term Sustainable Development Strategy and medium and short term Development/Action Programs/Plans. There were elaborated proposal for thematic indicator system for Climate change adaptation strategy for Salacgrīva coastal municipality (next chapter). ICG being directly linked with the planning/actions for climate change adaptation do require mutual integration.

Municipal climate change governance (MCCG) should simultaneously achieve synergistic relationship between environmental quality issues and local socio-economic development tasks, and not forgetting about sustainability governance dimension. Finally, the monitoring system should be based on indicator approach (there are test version of IS for Salacgriva municipality designed during our R\&D project). However, disciplinary climate change adaptation (CCA) planning is a very new field of municipal governance, which, at this moment only Salacgriva municipality has got one (CCA Strategy 2011). Three Latvian coastal cities (Riga, Jurmala and Liepaja) have signed the Covenant of Mayors and elaborated sustainable energy action plans, but other/rural coastal municipalities are not such active. To implement climate change adaptation related action disciplinary and/or integrated, the well defined and elaborated set of municipal governance (MG) instruments shall be on place, containing all six principal classes of instruments. Instrument classes for MCCG comprise traditionally known ones, which could be grouped as following (Ernšteins 2008): political and legislative; administrative and institutional; planning; economic and fiscal; infrastructure development; and, especially, communication instruments (besides 4 basic complementary instruments of communication incl. also such known tools like advisory activities, voluntary agreements etc). Particular group of MG instruments are monitoring tools (incl. Indicators), being cross-instrumental. Currently one can see that (1) not all of these instrument groups are actively used even in overall MG, (2) the application of these instruments are not still recognized for MCCG, (3) in case some of instruments are recognized, there is no yet complementary and integrated application of them. The study shows that the essential issue is working both professionally and individually with particular MCCG communication instruments - environmental information, education \& training, participation and environment/climate friendly behavior - complementary development and implementation, and contributing to ensure coherent activities of the MCCG Communication network involved actors.

Integration principle within municipal CCG shall include 5 "complementary dimensions" as for our collaboration governance model (Ernšteins 2008): (1) integration of all groups of instruments, (2) integrative stakeholders participatory process, (3) horizontal integration among thematic sectors and vertical integration among administrative levels, and (4) integrative monitoring (incl. governance indicators), (5) integration of governance communication all components in order to facilitate of the above mentioned integration processes and contents.

\section{Thematical indicator system developments for coastal municipalities}

Continuing indicator system studies during our step-wise realized R\&D program there have been developed and partially tested several thematical indicator systems. Due to limited administrative and financial resources at the municipalities testing were often done by project means and during project timing and traditionally based on selected stakeholders and experts' interviews as well as focus group/round table discussions. Here following are presented two examples of thematical indicator systems, elaborated and discussed during our municipality-university partnership projects (2011-2013), having only theoretical impact on further studies and territorial indicator systems developments since those mentioned proposals have not been implemented in practice by particular municipality council decisions. In the Table 2. there are represented adapting to climate change indicators system proposal (within frame of EU Interreg project CoastSust), but in the Table 3. there is to be seen healthy and environmentally friendly food life cycle governance indicator list (within frame of EU Interreg project Foodweb), both IS being developed and tested at the Salacgriva coastal municipality.

Table 2. Adapting to climate change indicators system: Salacgriva municipality (Source: Ernšteins et al. 2014)

\begin{tabular}{|c|c|c|}
\hline & Policy & Indicators \\
\hline \multicolumn{3}{|r|}{ Nature dimension } \\
\hline \multirow{8}{*}{$\begin{array}{l}\text { Climate change } \\
\text { adaptation programmes } \\
\text { for: }\end{array}$} & \multirow[b]{2}{*}{ water management } & Bathing water quality, guided and mandatory value exceeding \\
\hline & & Water treatment and supply and wastewater treatment energy capacity \\
\hline & waste management & Share of general population/ enterprises involved in waste management system \\
\hline & \multirow{3}{*}{ coastal management } & Air temperature, rainfall, nebulosity and average wind speed in Ainaži \\
\hline & & $\begin{array}{l}\text { Number of stormy days in Salacgrīva and Ainaži. Water level at the Salaca } \\
\text { estuary }^{3} \text {. }\end{array}$ \\
\hline & & $\begin{array}{l}\text { Number of tree-cutting permissions for non-forest lands and their spatial } \\
\text { distribution }\end{array}$ \\
\hline & \multirow{2}{*}{$\begin{array}{l}\text { biodiversity } \\
\text { management }\end{array}$} & Forest clearcut and reforestation, area and per cent from total forest area \\
\hline & & Salmon Salmo salar: amount of smolts in the Salaca river \\
\hline
\end{tabular}




\begin{tabular}{|c|c|c|}
\hline \multicolumn{3}{|r|}{ Economic dimension } \\
\hline \multirow{8}{*}{$\begin{array}{l}\text { Climate change } \\
\text { adaptation policy } \\
\text { action programme for: }\end{array}$} & \multirow{2}{*}{$\begin{array}{l}\text { energy and } \\
\text { production } \\
\text { management }\end{array}$} & Renewable energy share in the heat supply in Salacgrivva municipality \\
\hline & & Number and volume of implemented energy efficiency projects per year \\
\hline & \multirow{3}{*}{$\begin{array}{c}\text { business and tourism } \\
\text { management }\end{array}$} & Share of forest areas managed meeting FSC and PEFC standards \\
\hline & & Share of biologically and non-biologically managed agricultural land \\
\hline & & $\begin{array}{l}\text { Number of tourist lodging sites with different types of ecological certificates in } \\
\text { Salacgrīva district }\end{array}$ \\
\hline & \multirow{3}{*}{$\begin{array}{l}\text { transport and } \\
\text { infrastructure } \\
\text { management }\end{array}$} & $\begin{array}{l}\text { Salacgriva district public transport operation, number of passengers per year, } \\
\text { number and total length of local bus lines }\end{array}$ \\
\hline & & $\begin{array}{l}\text { Bicycle infrastructure development: length of built-up and marked bicycle roads, } \\
\text { number of parkings. }\end{array}$ \\
\hline & & $\begin{array}{l}\text { Buried supply network electrical cable length and share of them in overall length } \\
\text { of supply network }\end{array}$ \\
\hline \multicolumn{3}{|r|}{ Social dimension } \\
\hline \multirow{4}{*}{$\begin{array}{l}\text { Climate change } \\
\text { adaptation policy } \\
\text { action programme for: }\end{array}$} & \multirow{4}{*}{ social management } & Share of population living in areas at climatic risk \\
\hline & & Number ant total duration of electricity supply interruptions \\
\hline & & Households number and share, owning a second home \\
\hline & & Insurance cases number and volume of natural disasters \\
\hline \multicolumn{3}{|r|}{ Governance and communication dimension } \\
\hline \multirow{4}{*}{$\begin{array}{l}\text { Climate change } \\
\text { adaptation policy } \\
\text { action programme for: }\end{array}$} & \multirow{2}{*}{$\begin{array}{l}\text { governance } \\
\text { management }\end{array}$} & $\begin{array}{l}\text { Environment and climate change adaptation friendly action share in the } \\
\text { population daily routine }\end{array}$ \\
\hline & & $\begin{array}{l}\text { Population ecological footprint, overall for municipality and separately for local } \\
\text { communities }\end{array}$ \\
\hline & \multirow{2}{*}{$\begin{array}{l}\text { Communication } \\
\text { management }\end{array}$} & $\begin{array}{l}\text { Number and frequency of publications about environment and climate change in } \\
\text { local media }\end{array}$ \\
\hline & & $\begin{array}{l}\text { Number and frequency of published opinions and information level about climate } \\
\text { change }\end{array}$ \\
\hline
\end{tabular}

Table 3. Healthy and environmentally friendly food life cycle (food system) governance indicator list: Salacgriva municipality

\begin{tabular}{l|l|l}
\hline \multicolumn{1}{c|}{ Action group } & \multicolumn{1}{c}{ Indicator } & \multicolumn{1}{c}{ Measure unit } \\
\hline $\begin{array}{l}\text { Agriculture and primary } \\
\text { food processing }\end{array}$ & Biological farms & number, share \%, agricultural land share \% \\
\cline { 2 - 3 } $\begin{array}{l}\text { Food processing and } \\
\text { production }\end{array}$ & $\begin{array}{l}\text { Individual fishermen, including inland waters } \\
\text { craftsmen }\end{array}$ & number; product output LVL/EUR \\
\cline { 2 - 3 } & Agricultural co-operation & number \\
\hline \multirow{2}{*}{$\begin{array}{l}\text { Food distribution to } \\
\text { consumers }\end{array}$} & $\begin{array}{l}\text { Individual sellers of self grown produce in the } \\
\text { local market }\end{array}$ & number of members \\
\cline { 2 - 3 } & Local produce for the consumption by population & \% of population; character of distribution \\
\cline { 2 - 3 } & Local produce in school kitchens & $\%$ \\
\cline { 2 - 3 } & Healthy food departments in stores & $\%$ of all stores \\
\hline \multirow{2}{*}{$\begin{array}{l}\text { Consumption habits and } \\
\text { population knowledge } \\
\text { about environmentally } \\
\text { friendly and healthy food }\end{array}$} & Healthy food purchasing frequency & assessment \\
\cline { 2 - 3 } & Dietary use of self grown food & assessment \\
\cline { 2 - 3 } & Motivation of not using healthy food & group \% distribution \\
\cline { 2 - 3 } & Knowledge assessment and self-assessment & assessment \\
\hline
\end{tabular}




\section{Territorial indicator system developments for coastal municipalities - sustainable development governance}

Let's look at the particular territorial indicator system case of local municipality and its sustainable development planning, but in the case where municipality is also a coastal territory. In 2013 during our collaboration study with municipality, as the pilot, the fully functioning sustainable development governance indicator system has been for the first time in Latvia produced and implemented for Saulkrasti coastal municipality, and, being accepted by local authority as a part of supervision monitoring to be done for municipal long-term development strategy governance legally required document - Sustainable Development Strategy. In 2015-16 we continued the work and the first fullscale assessment of the governance of sustainable development took place. Every couple of years the full-scale assessment of sustainable development governance will take place and municipal Sustainability Review (as for our nation-wide municipal policy initiative/innovation) will be produced as new municipal policy document in Latvia. Right now we are in this process and results are to be discussed in public and Review finalized and published. Following this implementation of an SDG indicator system, we were able to assess it from several thematic and territorial viewpoints. The indicator system is updated after technical evaluation of all indicators: some indicators are excluded or changed with others, some complex indicators are divided into separate indidators, distributed by better corresponding sectors. Number of strategical indicators are increased. Now the system contains structured list of 66 indicators (Table 4), grouping them into sustainability dimensions and integrative problem areas, being as a formal/mandatory part of the municipal sustainable development strategy, including: 15 environmental dimension indicators, divided in 7 thematic groups; 21 economic dimension indicators, divided in 6 thematic groups; 18 social dimension indicators, divided in 5 thematic groups; 7 governance dimension indicators, divided in 3 thematic groups; and 5 integral indicators: demographical and common indices. Most of indicators are integrated at least for 2 dimensions of sustainability. In this pilot system 21 of indicators directly or indirectly describe the coastal impacts and processes. The manual of usage of indicator system and indicators for sustainability monitoring was produced and municipal personal were trained. Leading indicators for all dimensions (bolded) and some sectors (bold italic) are determined (bolded in table).

Table 4. Sustainable development governance indicator system for Saulkrasti coastal municipality (v.2016 after revision)

\begin{tabular}{|c|c|c|}
\hline No. & Group (sector) & Indicator name \\
\hline \multicolumn{3}{|r|}{ Strategic (integral) indicators I } \\
\hline 1 & \multirow{2}{*}{ Demography } & I1.1. Number of inhabitants \\
\hline 2 & & I1.2. Long-term migration: number, balance \\
\hline 3 & \multirow{3}{*}{ General indices } & I2.1. Area development, index and index ranking \\
\hline 4 & & I2.2. Area atractivity, index \\
\hline 5 & & I2.3. Services availability, index \\
\hline \multicolumn{3}{|r|}{ Nature dimension $\mathrm{D}$} \\
\hline 6 & \multirow{3}{*}{ Nature, biodiversity } & D1.1. Forest area dynamics: hectares per year, ratio, $\%$ \\
\hline 7 & & D1.2 Wood-cutten permissions out of wood: permissions per year \\
\hline 8 & & D1.3. Natural and semi-natural habitats in total area, $\%$ \\
\hline 9 & \multirow{4}{*}{ Household impacts } & D2.1. Collected ammount of waste: cu.metres per year \\
\hline 10 & & D2.2. Satisfaction of population by waste management: opinions, $\%$ \\
\hline 11 & & D2.3. Household provision of centralized water supply and sewerage: $\%$, part of territory, $\%$ \\
\hline 12 & & D2.4. Sewage treatment plant emissions to water: main pollutant groups, $\%$ tons per year \\
\hline 13 & \multirow{2}{*}{ Air quality } & D3.1. Greenhouse gas emissions from municipal and industrial sector: tons per year \\
\hline 14 & & D3.2. Air quality by lichenoindication: index \\
\hline 15 & \multirow{2}{*}{ Surface waters, sea } & D4.1. Swimming water quality in the sea: excess, $\%$ of measurement \\
\hline 16 & & D4.2. Small river water quality by bioindication: index \\
\hline 17 & \multirow{2}{*}{$\begin{array}{l}\text { Land resources, } \\
\text { construction }\end{array}$} & D5.1. Building permissions and their types: number by types \\
\hline 18 & & D5.2. Natural base land transformation: hectares per year, \% woodlands, agr.lands. \\
\hline 19 & Coast as resource & D6.1. Coastal erosion: metres per year \\
\hline 20 & Environment general & D7.1. Population opinion on the state of the environment: opinions \%; change of opinions, $\%$ \\
\hline \multicolumn{3}{|r|}{ Economic dimension $\mathbf{E}$} \\
\hline 21 & \multirow{2}{*}{$\begin{array}{l}\text { Labour force and } \\
\text { their reserve }\end{array}$} & E1.1. Dependency ratios at inhabitants: young-age dependency, age dependency, $\%$ \\
\hline 22 & & E1.2. Occupied posts: number \\
\hline 23 & \multirow{2}{*}{ Budget, finances } & E2.1. Structure of municipality budget: total, EUR; \% by main positions \\
\hline 24 & & E2.2. Realised infrastructure projects, financing: EUR per year \\
\hline 25 & \multirow{3}{*}{ Entrepeneurship } & E3.1. Registered businesses and economically active statistical units, number per year \\
\hline 26 & & E3.2. Profile of economical activities, $\%$ distribution by sectors \\
\hline 27 & & E3.3. Skulte port activities \\
\hline 28 & \multirow{4}{*}{ Mobility } & E4.1. Proportion of hard-covered roads in all network of roads: $\% ; \mathrm{km} / \mathrm{sq} . \mathrm{km}$ \\
\hline 29 & & E4.2. Registered vehicles: number \\
\hline 30 & & E4.3. Public transport traffic: number of passengers, lines \\
\hline 31 & & E4.4. Cycling path lenght: km \\
\hline
\end{tabular}




\begin{tabular}{|c|c|c|}
\hline No. & Group (sector) & Indicator name at v.2016 \\
\hline 32 & Energy sources & E5.1. Fuel uses by type municipal and industrial sector: tons per year, $\%$ of overall \\
\hline 33 & \multirow{7}{*}{ Tourism } & E6.1. Number of tourism and related services \\
\hline 34 & & E6.11. Tourism development \\
\hline 35 & & E6.2. Main characteristics of tourism services: beds, bed load \% \\
\hline 36 & & E6.3. Staff at tourism industry: number \\
\hline 37 & & E6.4. Tourism information center: financial resources, eur, number of attendance \\
\hline 38 & & E6.5. Certified environmental friendly tourism accomodations, number and \% from total \\
\hline 39 & & E6.6. Opinions for coastal improvement and tourism services, \% distribution \\
\hline 40 & \multirow{2}{*}{ Commercial services } & E7.1. Grocers availability: opinions \% \\
\hline 41 & & E7.2. Manufactured goods availability: opinions \% \\
\hline & & Social dimension $\mathrm{S}$ \\
\hline 42 & \multirow{4}{*}{ Health care } & S1.1. Opinions for health services, \% distribution \\
\hline 43 & & S1.2. Health care availability: opinions $\%$ \\
\hline 44 & & S1.3. Dantist availability: opinions \% \\
\hline 45 & & S1.4. Senior authorities availability: opinions $\%$ \\
\hline 46 & \multirow{3}{*}{ Culture, sports } & S2.1. Municipal funding for supporting of culture and sports infrastructure and events: eur per year \\
\hline 47 & & S2.2. Culture and sports infrastructure availability: opinions \% \\
\hline 48 & & S2.3. Libraries and public internet access points, availability: opinions $\%$ \\
\hline 49 & \multirow{4}{*}{$\begin{array}{l}\text { Social and physical } \\
\text { safety }\end{array}$} & S3.1. Registered unemployment and their dynamic, \% of working-age people, number \\
\hline 50 & & S3.2. Benefit costs: eur per year, number of supported people \\
\hline 51 & & S3.3. Crime statistics, level and \% by main positions \\
\hline 52 & & S3.4. Average incomes per capita: eur \\
\hline 53 & \multirow{5}{*}{ Education } & S4.1. Number o pupils in the "key" classes \\
\hline 54 & & S4.2. Mutual payments among the municipalities for education services, thsd. eur \\
\hline 55 & & S4.3. Interest education attendance, number of pupils \\
\hline 56 & & S4.4. The availability of pre-school institutions: opinions \% \\
\hline 57 & & S4.5. General education availability: opinions \% \\
\hline 58 & \multirow{2}{*}{ Household } & S5.1. Habitat comfort level: \% by services \\
\hline 59 & & S5.2. Number of people at household area unit \\
\hline & & Governance dimension $P$ \\
\hline 60 & \multirow{2}{*}{ Governance } & P1.1. Opinion for municipal management, $\%$ by types \\
\hline 61 & & P1.2. Opinion for municipal planning, $\%$ by types \\
\hline 62 & \multirow{3}{*}{$\begin{array}{l}\text { Governance } \\
\text { communication }\end{array}$} & P2.1. Number of unique visitors at municipal website \\
\hline 63 & & P2.2. Local newspaper, circulation \\
\hline 64 & & P2.3. Opinion for municipal communication, \% by types \\
\hline 65 & \multirow{2}{*}{$\begin{array}{l}\text { Activities in non- } \\
\text { governmental sector }\end{array}$} & P3.1. Registered NGO's, number \\
\hline 66 & & $\begin{array}{l}\text { P3.2. Local governments and NGO's cooperation: projects per year; municipal co-financing, } \\
\text { EUR }\end{array}$ \\
\hline
\end{tabular}

\section{General conclusions}

Integrated coastal governance as principal coastal governance approach has been actively developed in EU, incl. by voluntary developing international and national strategies and, finally, has been also setting coresponding requirements for national/regional planning for all coastal member countries. Even known, but still not widely accepted and used is the application of coastal indicators systems, what is to be done in complementary interrelation with generally known, but in following complementary six classes set, coastal governance instruments as political and legal, planning, institutional and administrative, infrastructure, economic/financial and also communication ones.

Very general problem for coastal governance practice development particularly at the local municipal level is to be seen at both ends of governance cycle - science and policy. Principal integration approach is necessary at any step of the process to be realized - from coastal science to municipal monitoring and sustainability indicators into ICG. General transition or interface system is to be seen as necessary step for local authorities and local municipal monitoring, and, especially, IS are to be playing crusial role here. Such interface system have been started to test step-wise during realization of various our research and development projects: to translate and integrate academic coastal science based results into to be designed an applied municipal land-water boundary monitoring and indicator system; to integrate this auditing knowledge into the whole municipal coastal governance cycle process/products with innovating and facilitating ICG decision-making and policy renewal, complementary instruments based planning and implementation; to design an integrated coastal science and governance communication content/products and to prepare stakeholders participated communication process with integrated instruments development. 
ICG studies in Latvia still recognize various traditional problem fields, but particularly - missing complex socio-ecological system approach and the coast as local general development resource approach. There is to be stated basic need for sustainable coastal governance (SCG) understanding and collaboration governance principle application at all sectors, levels, target group dimensions complementary and mandatory development of SCG instruments, particularly, coastal communication complementary instruments - information, education, participation and behavior. Also the climate change effects are increasingly impacting both sides of coastal border areas requesting skills \& knowledge development within local communities in sustainable usage of nature resources and its relations to socio-economic factors as well as design and disciplinary and/or integrative development of climate change adaptation planning within municipal sustainable development strategy and medium/short term action plans.

In the first stage of our research-and-development programme, there were elaborated an initial SCD indicator system proposal for national level in Latvia, which was recognizing main typical features of nature-environmental and socio-economic conditions, spatial scale and data gathering selective differences as well as also identifying institutions and actors to be involved. That IS proposal comprised only 24 indicators and, importantly included additionally indicators for the assessment of SCG capacities and, particularly, the necessary developments of the coastal communication process. However, further testing and elaborations was not taking place outside project applications and governmental authorities interest has not been sufficiently raised because of relatively high expenditures for creating and maintenance of IS, in general.

In the same time, mentioned IS made further impact on various thematical and territorial indicator systems developments, but for municipal planning and practice as described in this paper. Requirements have been elaborated for construction of coastal municipal indicators itself and building of other thematical and, particularly, territorial/municipal indicator systems (IS) as a complementary tools to be used for SCG if there are no coastal governance planning documents. Expert based testing do recognize perspectives of such thematical IS, but practice based testing is mainly still missing, what would be especially important, when approaching nation-wide cross-level and cross-sectors reaching development governance (sustainable development governance) IS in nearby future. As important step ahead is to be seen development of the first territorial IS at municipality level, being legally added to the mandatory municipal development planning system and document. At Saulkrasti municipality IS proposal was designed and fully implemented, being used now for supervision of municipal Sustainable development strategy.

Also is to be mentioned, the eventual perspective SCG development instrument - coastal indicators observatory system development shall be discussed for sea-land border area administrative territory, characterized by vertical levels complementary integration, respecting coastal area typology, using physical, socio-economical and governance characteristics as for understanding and collaboration for SCG as specific socio-ecological systems.

\section{Acknowledgements}

R\&D data were collected, elaborated and paper prepared within the framework of Latvian National research program project on Environmental diversity and sustainable governance (SUSTINNO, 2014-2017). There shall be acknowledged master students involved into field works.

\section{References}

Alberta, C.; Bonn, A.; Burkhard, B. et al. 2016. Towards a national set of ecosystem service indicators: insights from Germany, Ecological Indicators 61: 38-48. https://doi.org/10.1016/j.ecolind.2015.08.050

Becker, J. 2005. Measuring progress towards sustainable development: an ecological framework for selecting indicators, Local Environment 10(1): 87-101. https://doi.org/10.1080/1354983042000309333

Bossel, H. 2001. Assessing viability and sustainability: a systems-based approach for deriving comprehensive indicator sets, Conservation Ecology 5(2): 12. https://doi.org/10.5751/ES-00332-050212

Bowen, R. E.; Riley, C. 2003. Socio-economic indicators and integrated coastal management, Ocean \& Coastal Management 46: 299-312. https://doi.org/10.1016/S0964-5691(03)00008-5

CCA Strategy. 2011. Salacgrīvas novada klimata pārmaiņu adaptācijas stratēgija [online], (Salacgriva municipality Climate Change Adaptation Strategy), [cited 02 March 2017] (in Latvian). Available from Internet: http://www.salacgriva.lv/lat/salacgrivas_novads/zalais_novads/?text_id=6401

Comino, E.; Ferretti, V. 2016. Indicators-based spatial SWOT analysis: supporting the strategic planning and management of complex territorial systems, Ecological Indicators 60: 1104-1117. https://doi.org/10.1016/j.ecolind.2015.09.003

Ernšteins, R. 2008. Sustainable coastal development in Latvia: Collaboration communication and governance inperative, in Sustainable Coastal Development: Collaboration Governance. Riga, University of Latvia Publishing, 159-179.

Ernšteins, R.; Kauliņš, J.; Kudreņickis, I. 2009. Sustainable coastal development indicator system studies in Latvia. Sustainable Development and Planning IV, WIT Transactions on Ecology and the Environment, Vol. 120, WIT Press, 653-664. https://doi.org/10.2495/sdp090612

Ernšteins, R.; Kauliņš, J.; Līce, E.; Štāls, A. 2011. Integrated coastal management for local municipalities in Latvia: sustainability governance and indicator system, WIT transaction to The Built Environment 149: 29-40. 
Kaulins, J.; Ernsteins, R.; Kudrenickis, I.; Lontone, A.; Zilniece, I. Municipal thematical and territorial indicator systems for sustainable socio-ecological coastal governance

Ernšteins, R.; Lontone-Ieviņa, A.; Kauliņš, J.; Strazdiņ̌̌, J.; Kudreņickis, I.; Z̄ilniece, I.; Ķepals, A. 2014. Municipal climate change adaptation governance in Latvia: cross-sectoral and multi-instrumental understanding, Regional Formation Studies 3(14): 40-52. https://doi.org/10.15181/rfds.v14i3.862

Hezri, A.; Dovers, S. 2006. Sustainability indicators, policy and governance: issues for ecological economics, Ecological Economics 60: 86-99. https://doi.org/10.1016/j.ecolecon.2005.11.019

Kudrenickis, I.; Ernsteins, R.; Kaulins, J. 2016. Sustainable coastal science-policy-practice interface development: municipal coastal governance indicator system, Environmental Science 1: 255-264.

Marti, X.; Lescrauvaet, A-K.; Borg, M.; Valls, M. (Eds.). 2007. Indicators Guidelines: To adopt an indicators-based approach to evaluate coastal sustainable development. DEDUCE Consortium, Interreg IIIc, Barcelona. 98 p.

Mascarenhas, A.; Coelho, P.; Subtil, E.; Ramos, T. B. 2010. The role of common local indicators in regional sustainability assessment, Ecological Indicators 10: 646-656. https://doi.org/10.1016/j.ecolind.2009.11.003

Mascarenhas, A.; Nunes, L.; Ramos, T. B. 2014. Exploring the self-assessment of sustainability indicators by different stakeholders, Ecological Indicators 39: 75-83. https://doi.org/10.1016/j.ecolind.2013.12.001

Moldan, B.; Janoušková, S.; Hák, T. 2012. How to understand and measure environmental sustainability: indicators and targets, Ecological Indicators 17: 4-13. https://doi.org/10.1016/j.ecolind.2011.04.033

Moreno, S.; Fidelis, T. 2015. Local sustainability indicators in Portugal: assessing implementation and use in governance contexts, Journal of Cleaner Production 86: 289-300. https://doi.org/10.1016/j.jclepro.2014.08.002

Pužulis, A. 2010. Rīgas jūras līča piekrastes teritorijas noteikšana (Definition of coastal zone at Gulf of Riga; Riga planning region, 2010) [online], [cited 09 March 2017] (in Latvian). Available from Internet: http://www.rpr.gov.lv/uploads/filedir/Uzraudziba/Piekrastes_teritorijas_noteiksana/piekrastes_robezas.pdf

Rinne, J.; Lyytimäki, J.; Kautto, P. 2013. From sustainability to well-being: lessons learned from the use of sustainable development indicators at national and EU level, Ecological Indicators 35: 35-42. https://doi.org/10.1016/j.ecolind.2012.09.023

Rydin, Y.; Holman, N.; Wolff, E. 2003. Local Sustainability Indicators, Local Environment 6: 581-589. https://doi.org/10.1080/1354983032000152707

Valtenbergs, V.; González, A.; Piziks, R. 2013. Selecting indicators for sustainable development of small towns: the case of Valmiera municipality, Procedia Computer Science 26: 21-32. https://doi.org/10.1016/j.procs.2013.12.004 